\title{
1,3-Dipolar Cycloaddition of Azomethine Ylides to Alkenylboronates: Synthesis of Boronic Ester Substituted Pyrrolidine Derivatives and Asymmetric Approaches
}

\author{
Kyukwan Zong \\ Division of Chemical Education, Chonbuk National University, Jeonju 651-756, Korea. "E-mail: kzong@chonbuk.ac.kr \\ Received February 16, 2005
}

Key Words : Azomethine ylide, 1,3-Dipolar cycloaddition, Alkenylboronic esters

\begin{abstract}
1,3-Dipolar cycloadditions ${ }^{1}$ have been known as one of the highly useful synthetic methodologies which provide a variety of biologically important heterocycles. Among those, the cycloaddition of an azomethine ylide to an alkene affords a pyrrolidine moiety which is another very useful class of compounds for natural product synthesis. ${ }^{2}$ For instance, 3pyrrolidinol derivatives have recently attract attention in novel routes to prolyl peptides and cyclopeptide alkaloides. Although 3-pyrrolidine derivatives are commercially available, the number of this type of derivatives is limited and valuable enough to explore further. There are several reports of the synthesis of 3-pyrrolidinol derivatives. ${ }^{3}$ Intrigued with those literature, we envisioned that the cycloaddition reaction of alkenylboronates with azomethine ylides might afford 3-boronic ester substituted pyrrolidine derivatives.
\end{abstract} The reason we chose alkenylboronate as a dipolarophile is that the boronic ester functionality can be converted into a variety of other useful functionalities such as alcohol, amine, aldehyde, caboxylic acid, and others. Here we report that 1,3-dipolar cycloaddition reaction of alkenylboronates with azomethine ylides and asymmetric cycloaddition using chiral auxilaries equipped to vinylboronates.

First, we examined vinylboronate $\mathbf{1}$ and ester and toluenesulfonyl substituted vinylboronic esters, $\mathbf{2}$ and $\mathbf{3}$, which were prepared from hydroboration and transesterification of methyl propiolate and ethynyl $p$-toluenesulfone respectively. ${ }^{4}$ The cycloaddition of vinylboronate 1 to in situ generated $N$ benzyl azomethine ylide was pretty much sluggish to afford cycloadduct only $20 \%$ yield under various conditions. However, when an ester or sulfone substituted alkenylboronate, $\mathbf{2}$ or $\mathbf{3}$, were employed, the reaction became much accelerated and smoothly proceeded to afford the product in good yields ( $85 \%$ and $75 \%)$. It may be noticed that electron deficient substituent in the alkenylboronate might activate this dipolarophile toward azomethine ylide. Similarly, $N$-methyl azomethine ylide also was equally good toward the activated dipolarophile 2 to give the product in good yield (scheme 1).

Then we employed a different type azomethine ylide precursor, $N$-(methoxymethyl)- $N$-(trimethylsilylmethyl)benzylamine, which is triggered into an active ylide upon catalytic treatment of a strong acid. We were delighted to find that the reaction became much facilitated and afforded the products in good yields. The reaction of $\mathbf{1}$ with $\mathbf{1 0}$ under standard condition afforded the cycloadduct 6 in $75 \%$ yield which was markedly improved when compared to Scheme

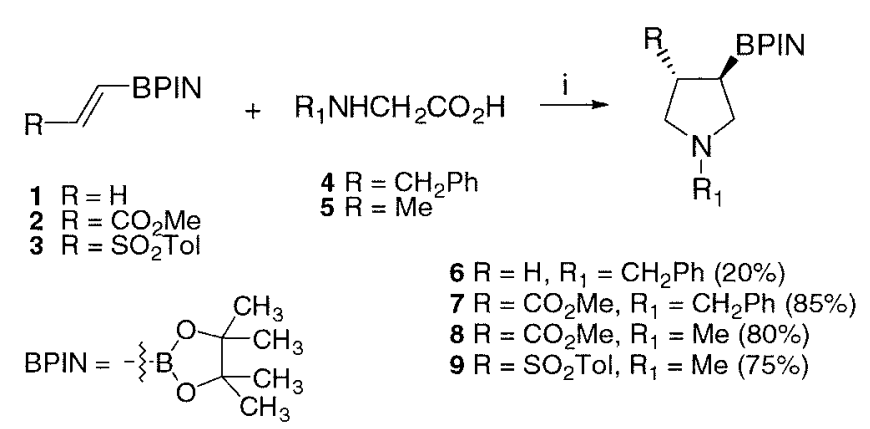

Scheme 1. Reaction conditions; i) $\mathrm{CH}_{2} \mathrm{O}$, toluene, reflux.

1. It should be noticed that the reaction was well done at low temperature and the vinylboronate $\mathbf{1}$ was not sluggish toward an ylide any more in this case. It is assumed that in situ generated ylide in Scheme 2 may stay longer due to low temperature and have enough time to react with a dipolarophile rather than under Scheme 1. The compound $\mathbf{6}$ was chosen and subjected to oxidation/debenzylation to give 3pyrrolidinol (12) in overall $83 \%$ yield which is commercially available (Scheme 2).

Then we turned our attention to asymmetric 1,3-dipolar cycloaddition by introducing appropriate chiral auxiliaries into a vinylboronic ester. There have been the number of examples of asymmetric 1,3-dipolar cycloadditions using chiral auxiliaries where most of them were attached onto the dipolarophiles. ${ }^{5}$ Some years ago, we reported the asymmetric cyloadditions of nitrile oxides to various alkenylboronates which were covalently bonded to $\alpha, \alpha, \alpha^{\prime}, \alpha^{\prime}$-Tetraaryl-1,3dioxolan-4,5-dimethanol (TADDOL) chiral auxiliaries. ${ }^{6}$ In

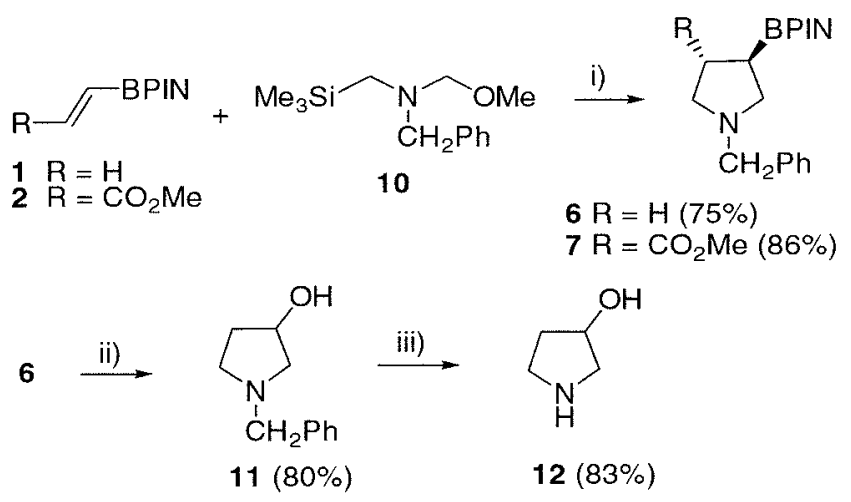

Scheme 2. Reaction conditions; i) $\mathrm{CF}_{3} \mathrm{CO}_{2} \mathrm{H}$ (cat.), $\mathrm{CH}_{2} \mathrm{Cl}_{2}, 0{ }^{\circ} \mathrm{C}$, ii) $\mathrm{H}_{2} \mathrm{O}_{2}, \mathrm{NaOH}$, iii) pd(c), $\mathrm{HCO}_{2} \mathrm{H}, \mathrm{CH}_{3} \mathrm{OH}$. 
<smiles>C=CB1OB(C=C)OB(C=C)O1</smiles><smiles>CC1(C)OC(C(O)(Br)Br)C(C(O)(Br)Br)O1</smiles>

13

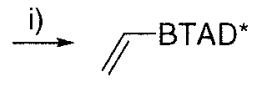

$20 \mathrm{Ar}=\mathrm{Ph}$

$21 \mathrm{Ar}=3,5-(\mathrm{Me})_{2} \mathrm{Ph}$

$22 \mathrm{Ar}=2-\mathrm{MePh}$

$23 \mathrm{Ar}=1$-naphthyl

$24 \mathrm{Ar}=2$-naphthyl

$25 \mathrm{Ar}=3,5-(\mathrm{Ph})_{2} \mathrm{Ph}$
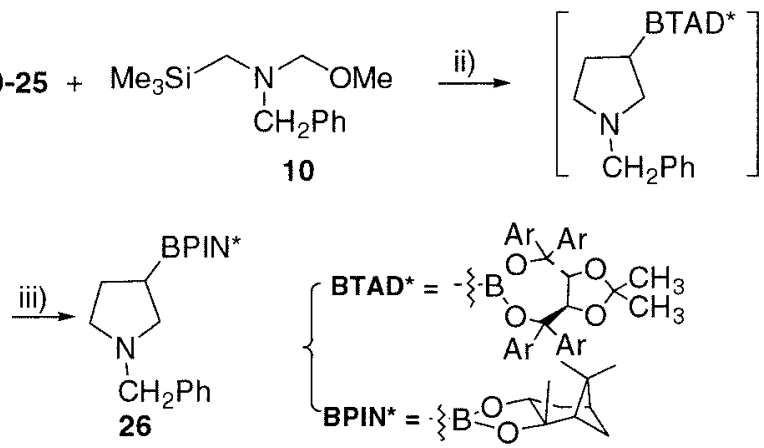

Scheme 3. Reaction conditions; i) toluene, Dean-Stark $\left(-\mathrm{H}_{2} \mathrm{O}\right)$, ii) $\mathrm{CF}_{3} \mathrm{CO}_{2} \mathrm{H}$ (cat.), $\mathrm{CH}_{2} \mathrm{Cl}_{2}, 0^{\circ} \mathrm{C}$, iii) (-)-pinanediol (-TAD*).

connection with the study, we were interested in investigating the asymmetric cyloaddition of azomethine ylides by employing the similar vinylboronic esters functionalized with TADDOLs. A series of vinyl boronic esters equipped with TADDOLs (20-25) were prepared from the condensation of the vinylboronic acid derivative 13 and TADDOLs (14-19). Here, vinylboronic acid derivative 13 is quite stable to handle whilst vinylboronic acid is easily polymerizable under usual condition. ${ }^{7}$ A series of compounds, 20-25 then reacted with the azomethine ylide to provide the cyloadduct intermediates which were then transformed into more stable (+)-pinanylboronic ester substituted pyrrolidine derivatives through transesterification with $(+)$-pinanediol because pinanylboronic ester is stable enough to be isolated. The cycloaddition reactions was performed under various temperatures $\left(25,0\right.$, and $\left.-45^{\circ} \mathrm{C}\right)$ and a couple of solvents (dichromethane and THF) but any significant differences in stereoselectivities were not observed in this study (Scheme $3)$. The diastereoselectivity of the cycloaddition of azomethine ylide to TADDOL functionalized vinylboronic esters showed $2: 1$ ratio in the lowest case, $4: 1$ ratio of two diastereomers in the highest case. The stereoselectivity was somewhat influenced by the types of aromatic group in the TADDOL moiety but yet not significantly. The result was summarized in Table 1. In conclusion, we demonstrated that the alkenylboronic esters were highly reactive dipolarophiles toward azomethine ylides and the boronic ester functionalized pyrrolidine derivatives obtained from 1,3-dipolar cycloaddition could be further transformed into more valuable compounds by manipulating boronic ester group. In addition, the asymmetric 1,3-dipolar cycloaddition using the
Table 1. The yields and diastereomeric ratio of the cycloadduct 26 in Scheme 3

\begin{tabular}{ccccr}
\hline Entry & $\begin{array}{c}\text { Vinylboronic } \\
\text { Esters }\end{array}$ & $\begin{array}{c}\text { Precursor } \\
\text { of Ylide }\end{array}$ & Yield (\%) $)^{a}$ & \multicolumn{1}{c}{$\mathrm{dr}^{b}$} \\
\hline 1 & $\mathbf{2 0}$ & $\mathbf{1 0}$ & 75 & $2: 1$ \\
2 & $\mathbf{2 1}$ & $\mathbf{1 0}$ & 70 & $2.7: 1$ \\
3 & $\mathbf{2 2}$ & $\mathbf{1 0}$ & 75 & $2.5: 1$ \\
4 & $\mathbf{2 3}$ & $\mathbf{1 0}$ & 70 & $4: 1$ \\
5 & $\mathbf{2 4}$ & $\mathbf{1 0}$ & 74 & $2.5: 1$ \\
6 & $\mathbf{2 5}$ & $\mathbf{1 0}$ & 73 & $3: 1$ \\
\hline
\end{tabular}

${ }^{a}$ The isolated yield of the compound $\mathbf{2 6}$ after transesterification of the intermediates with $(+)$ pinanediol. ${ }^{b}$ The diastereomers ratio $(\mathrm{dr})$ was determined by $300 \mathrm{MHz}$ proton NMR on both the compound $\mathbf{2 6}$ and the corresponding intermediates.

boronic esters equipped with TADDOLs as chiral auxiliaries revealed the synthetic potential of chirally functionalized alkenylboronic esters to provide optically active useful products.

Acknowledgment. The work was partially supported by Chonbuk National University and the author thanks to professor Richard H. Wallace for his guidance.

Supplementary Material Available: Typical procedures and full characterization data of $\mathbf{6}$ and $\mathbf{8}$ are available from the author upon request.

\section{References and Notes}

1. For reviews of 1,3-dipolar cycloadditions, see: (a) Carruthers, W. Cycloadditions in Organic Synthesis; Pergamon Press: Exter, Great Britain, 1990; Vol. 8, Chap. 6. (b) Huisgen, R. 1,3-Dipolar Cycloaddition Chemistry; Padwa, A., Ed.; Wiley-Interscience: New York, 1984; Vol. 1, Chap. 1. (c) Curran, D. P. Advances in Cycloadditions; Curran, D. P., Ed.; JAI Press: Greenwich, CT, 1988; Vol. 1, p 280.

2. For azomethine ylide cycloadditions, see: (a) Terao, Y.; Kotaki, H.; Imai, N.; Achiwa, K. Chem. Pharm. Bull. 1985, 33, 2762. (b) Padwa, A.; Chen, Y.-Y.; Chiachio, U.; Dent, W. Tetrahedron 1985, 41, 3529. (c) Meyers, A. I.; Fray, A. H. Tetrahedron Lett. 1992, 33, 3575 .

3. For the synthesis of 3-pyrrolidine derivatives, see: (a) Krether, R.; Pawalczyk, H. Tetrahedron Lett. 1966, 2591. (b) Lukes, R.; Pergal, M. Coll. Czech. Chem. Comm. 1962, 27, 1387. (c) Jaeger, E.; Biel, J. H. J. Org. Chem. 1965, 30, 740. (d) Belfaitah, A.; Isly, M.; Carboni, B. Tetrahedron Lett. 2004, 45, 1969. (e) Bowers Nemia, M. M.; Lee, J.; Joulli, M. M. Synth. Commun. 1983, 13, 1117. (f) Brown, H. C.; Vara Prasad, J. V. N.; Gupta, A. K. J. Org. Chem. 1986, 51, 4296.

4. Rasset-Deloge, C.; Martinez-Fresneda, P.; Vaultier, M. Bull. Soc. Chim. Fr. 1992, 129, 285.

5. For asymmetric 1,3-dipolar cycloadditions, see: (a) Kanemasa, S.; Kobayashi, S.; Nishiuchi, M.; Yamamoto, H.; Wada, E. Tetrahedron Lett. 1991, 32, 6367. (b) Curran, D. P.; Jeong, K.-S.; Heffner, T. A. J. Am. Chem. Soc. 1989, 111, 9238. (c) Kawanami, T.; Katsuki, T.; Yamaguchi, M. Bull. Chem. Soc. Jpn. 1987, 60, 4190.

6. Wallace, R. H.; Zong, K. J. Organomet. Chem. 1999, 581(2), 87.

7. Matteson, D. S. J. Am. Chem. Soc. 1962, 27, 3712. 